\title{
SHADING LEVELS AND PLANT GROWTH REGULATOR FOR FORMATION OF SCHIZOLOBIUM AMAZONICUM COMPACT SEEDLINGS
}

\author{
Eliana D. C. Binotti ${ }^{1}$, Flávio F. da S. Binotti ${ }^{1}$, Bruna Z. Lucheti ${ }^{1}$, Edilson Costa ${ }^{1}$, Adriana H. Pinto ${ }^{2}$ \\ ${ }^{1 *}$ Corresponding author. Universidade Estadual de Mato Grosso do Sul/ Cassilândia - MS, Brasil. \\ E-mail: dclia78@yahoo.com.br| ORCID ID: https://orcid.org/0000-0003-1760-0363
}

\section{KEYWORDS}

protected cultivation, plant environment, high-quality seedlings, plant growth reducer, Schizolobium amazonicum.

\begin{abstract}
Paricá (Schizolobium amazonicum) can be used for rehabilitation of degraded lands, timber manufacturing markets. However, for its planting, high-quality seedlings should be used. Thus, this study aimed to evaluate the effect of different types of paclobutrazol (PBZ) application and two shading levels on high-quality seedling production. As there was no replication of cultivation environments, we considered each one of them as an experiment. For each environment ( 35 and $50 \%$ shading screen), a completely randomized design was adopted, testing combinations of two types of PBZ application (direct seed immersion in $0.005 \% \mathrm{PBZ}$ solution; substrate hydration with $0.005 \% \mathrm{PBZ}$ solution; and $50 \%$ seed hydration and 50\% substrate hydration; plus, a control), with five replications and five seedlings per plot. The environments were evaluated by analysis of groups of experiments. Seedling growth was evaluated. Under 50\% shading, Paricá seedlings had better growth conditions. Application of $100 \%$ PBZ in substrate provided compact seedlings with larger dry root phytomass, besides being more practical.
\end{abstract}

\section{INTRODUCTION}

Schizolobium amazonicum is a tree species popularly known as 'Paricá'. It has fast initial-growth and great field growth potential (Caione et al., 2012). Its seeds are oval-shaped with epigeal germination, and its seedlings are phanerocotyledonal with primary root protrusion occurring within 24 hours (Braga et al., 2013). Mechanical scarification using electric grinders breaks seed dormancy, besides speeding up and standardizing germination and seedling emergence (Dapont et al., 2014), and thus ensuring seedling uniformity and fast formation.

The use of Paricá for timber harvesting or forest restoration requires a consistent program of high-quality seedling formation. Seedlings must have uniform initial growth at nursery phase, within a shorter time, successful transplanting, and initial field growth (Gondin et al., 2015), as well as lower mortality rates, which reduces replanting (Rosa et al., 2009). In order to obtain uniform seedlings that meet a successful reforestation program, growth regulator should be used to improve dry mass partitioning to both shoot and root.

Paclobutrazol (PBZ) has been studied in many crops as it is a growth regulator that reduces stem elongation. Its supply in tomato provides higher dry phytomass accumulation to roots and lower to shoot, decreasing total dry mass and seedling height (Seleguini et al., 2013). This way, it enables the production of compact plants with higher dry-mass partitioning to roots. This inhibitor of gibberellin biosynthesis can be applied by leaf spraying or directly to the soil. It is passively absorbed by the roots, stem, and leaves and has an upward or acropetal movement through the xylem (Benett et al., 2014).

In addition to the use of growth regulator at early stage, uniform and compact seedlings can be produced by promoting suitable environments where seedling quality and potential are increased at nursery phase. Therefore, protected environment types, covering materials, and shading levels should be verified to improve production environment conditions and produce high-quality seedlings.

Effects of temperature, oxygen and carbon-dioxide contents, light level, water availability, among others, on photosynthesis have enabled development of technologies to maximize crop yield, as well as assisting in agroclimatic crop zoning (Kluge et al., 2015). These effects can be observed since early-stage at seedling nursery, through growth and development stages, until reaching physiological maturity.

Recent studies on light levels for forest species revealed that $50 \%$ shading improves seedling quality. For S. amazonicum, this shade level was better than under full

\footnotetext{
${ }^{1}$ Universidade Estadual de Mato Grosso do Sul/ Cassilândia - MS, Brasil.

${ }^{2}$ Centro Universitário Una/ Belo Horizonte - MG, Brasil.

Received in: 6-28-2018

Accepted in: 8-14-2019
} 
sun ( $0 \%$ shade) (Gondin et al., 2015), whereas for jucá seedlings (Caesalpinia ferrea) it was better than 0 and 70\% (Lenhard et al., 2013), and for Physocalymma scaberrimum seedlings, it was better than 0, 30, 70, and $90 \%$ (Valadão et al., 2014).

It is then of utmost importance to evaluate growth reducer application methods and shading levels, as they may promote morphological changes that would improve párica seedling quality. Given the above, this study focused on evaluating the effects of different paclobutrazol application methods and two shading levels on production of high-quality $S$. amazonicum seedlings.

\section{MATERIAL AND METHODS}

The experiment was carried out at the State University of Mato Grosso do Sul - UEMS (Cassilândia Unit), between October and December 2016. The local geographical coordinates are $19^{\circ} 05^{\prime} \mathrm{S}, 51^{\circ} 48^{\prime} \mathrm{W}$, and 495 $\mathrm{m}$ altitude. According to Köppen, the local climate is classified as tropical rainy (Aw), with rainy summers and mostly dry winters. Annual mean rainfall and temperature are $1,520 \mathrm{~mm}$ and $24,1^{\circ} \mathrm{C}$, respectively.

Combinations of different application methods of paclobutrazol (PBZ) in Schizolobium amazonicum seeds and seedling substrate were tested in this study. The following treatments were performed: seed application with direct immersion in $0.005 \% \mathrm{PBZ}$ solution; substrate hydration with $0.005 \%$ PBZ solution; $50 \%$ seed immersion and 50\% substrate hydration, and no PBZ application (control). All these treatments were tested at two shading levels (35 and 50\%).
Two protected environments were used: (A1) wooden greenhouse $(6.0 \mathrm{~m}$ wide $\times 6.0 \mathrm{~m}$ long $\times 2.5 \mathrm{~m}$ high), side closure with $90^{\circ}$ incline, with full-length monofilament screen, and $35 \%$ shading mesh (Sombrite $\AA)$; (A2) galvanized steel greenhouse $(8.0 \mathrm{~m}$ wide $\times 18.0 \mathrm{~m}$ long $\times 3.5 \mathrm{~m}$ high), side closure with $45^{\circ}$ incline, full-length monofilament screen, and 50\% shading mesh (Sombrite $\left.{ }^{\circledR}\right)$.

Seeds were hydrated by direct immersion without aeration (via seed) for 23 hours at $25{ }^{\circ} \mathrm{C}$. Hydration time varied with treatment, being done until average seed water content was sufficient without primary root emission.

Schizolobium amazonicum seeds were purchased in Paragominas-PA (Brazil). First, they underwent mechanical scarification using a grinder to partially remove lateral integument. This was done to overcome dormancy by seed coating. After immersion in deionized water and PBZ, seeds were washed in deionized water and in running water to remove mucilage from hydration process. In each container, two seeds were sown. After seedling emergence, they were thinned out to one seedling per container.

Seedlings were produced in polyethylene plastic bags $(15 \mathrm{~cm} \times 25 \mathrm{~cm}-1.8 \mathrm{~L})$, using as a substrate a mixture of hillside soil (23.9\% organic matter), coarse sand, and medium expanded vermiculite at a 3: 2: 1 volume ratio, respectively. Table 1 shows the chemical analysis of the hillside soil.

TABLE 1. Chemical characteristics of a hillside soil from Cassilândia-MS (Brazil), 2016.

\begin{tabular}{|c|c|c|c|c|c|c|c|}
\hline $\mathrm{pH}$ & \multicolumn{3}{|c|}{--------cmol dm-3------- } & $\mathrm{mg} \mathrm{dm}^{-3}$ & cmolc. & \multicolumn{2}{|c|}{$\mathrm{g} \mathrm{dm}^{-3}$} \\
\hline $\mathrm{CaCl}_{2}$ & $\mathrm{Ca}$ & $\mathrm{Mg}$ & $\mathrm{Al}$ & $\mathrm{P}(\mathrm{Mel})$ & CEC & $\mathrm{OM}$ & $\mathrm{OC}$ \\
\hline 4.8 & 4.3 & 1.1 & 0.19 & 7.4 & 12.5 & 23.9 & 13.9 \\
\hline \multicolumn{2}{|c|}{$\mathrm{mg} \mathrm{dm}^{-3}(\mathrm{ppm})$} & \multicolumn{5}{|c|}{------- mg dm³ (ppm). Mehlich"1-------- } & $\%$ \\
\hline $\mathrm{S}$ & $\mathrm{B}$ & $\mathrm{Cu}$ & $\mathrm{Fe}$ & $\mathrm{Mn}$ & $\mathrm{Zn}$ & $\mathrm{Na}$ & BS \\
\hline 3.7 & 0.13 & 2.0 & 26 & 78.6 & 1.5 & Ns & 78.6 \\
\hline
\end{tabular}

$\mathrm{OM}=$ organic matter; $\mathrm{OC}=$ organic carbon; $\mathrm{BS}=$ base saturation

Seedlings were analyzed 60 days after emergence (DAE) since this species reaches ideal size for transplantation $(20 \mathrm{~cm}$ to $35 \mathrm{~cm}$ height) within that time. We assessed the following parameters: a) root collar diameter at $1 \mathrm{~cm}$ above substrate surface, b) plant height, d) shoot dry phytomass and e) root dry phytomass. Collar diameter $(\mathrm{mm})$ was measured with a digital caliper and plant height $(\mathrm{cm})$ with a metric ruler (from collar to the last leaf insertion). Watering was carried out twice daily (morning and afternoon) using a hand-watering can. All treatments were watered until substrate reached saturation without oxygen restriction.

Then, seedlings were harvested for the shoot and root dry weight $(\mathrm{g})$ analysis. First, seedlings were removed from containers using a spatula. After, they were washed in running water, and next shoot and roots were separated. Thereafter, collected materials were allocated in paper bags, kept in an oven with forced air circulation at $65^{\circ} \mathrm{C}$, for 72 hours, until constant weight. Subsequently, phytomass measures (g) were taken using an analytical scale. Total dry phytomass (TDP) was estimated by summing shoot and root dry weights. The relationship between plant height and collar diameter (H/CD) was also determined.

Temperature $\left({ }^{\circ} \mathrm{C}\right)$, relative humidity $(\%)$, and photosynthetically active radiation $\left(\mu \mathrm{mol} \mathrm{m} \mathrm{m}^{-2} \mathrm{~s}^{-1}\right)$ were measured between November and December 2016. Measurements of temperature (Figure 1) and relative humidity (Figure 2) were recorded every 10 minutes and stored in a data logger (mod. CDR-550). Photosynthetically active radiation (PAR) was measured on clear days (without cloud cover) at $10 \mathrm{am}$, using a quantum meter MQ-200 (Apogee Instruments, UT, USA) (Figure 3). 


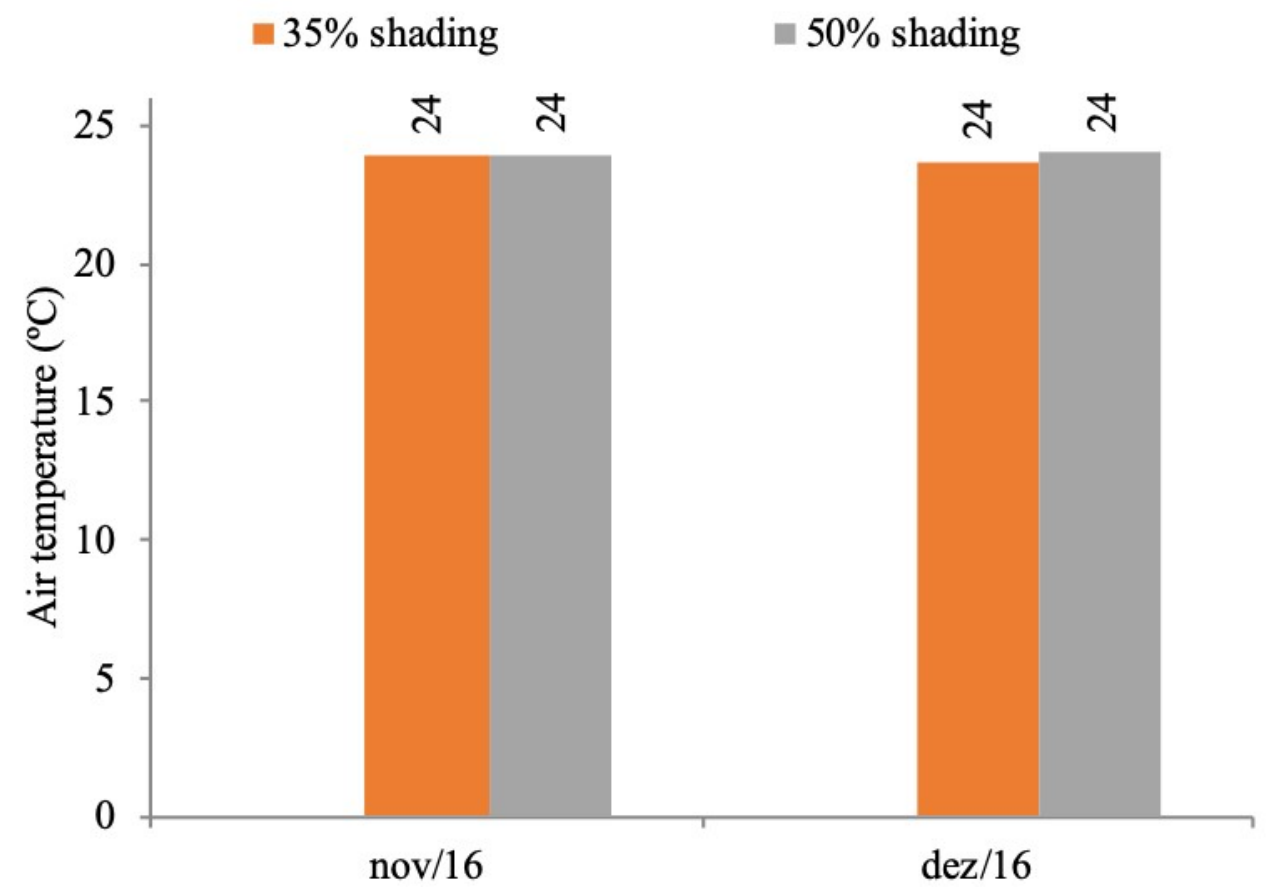

FIGURE 1. Temperature records in the cultivation environment. Cassilândia-MS (Brazil), 2016.

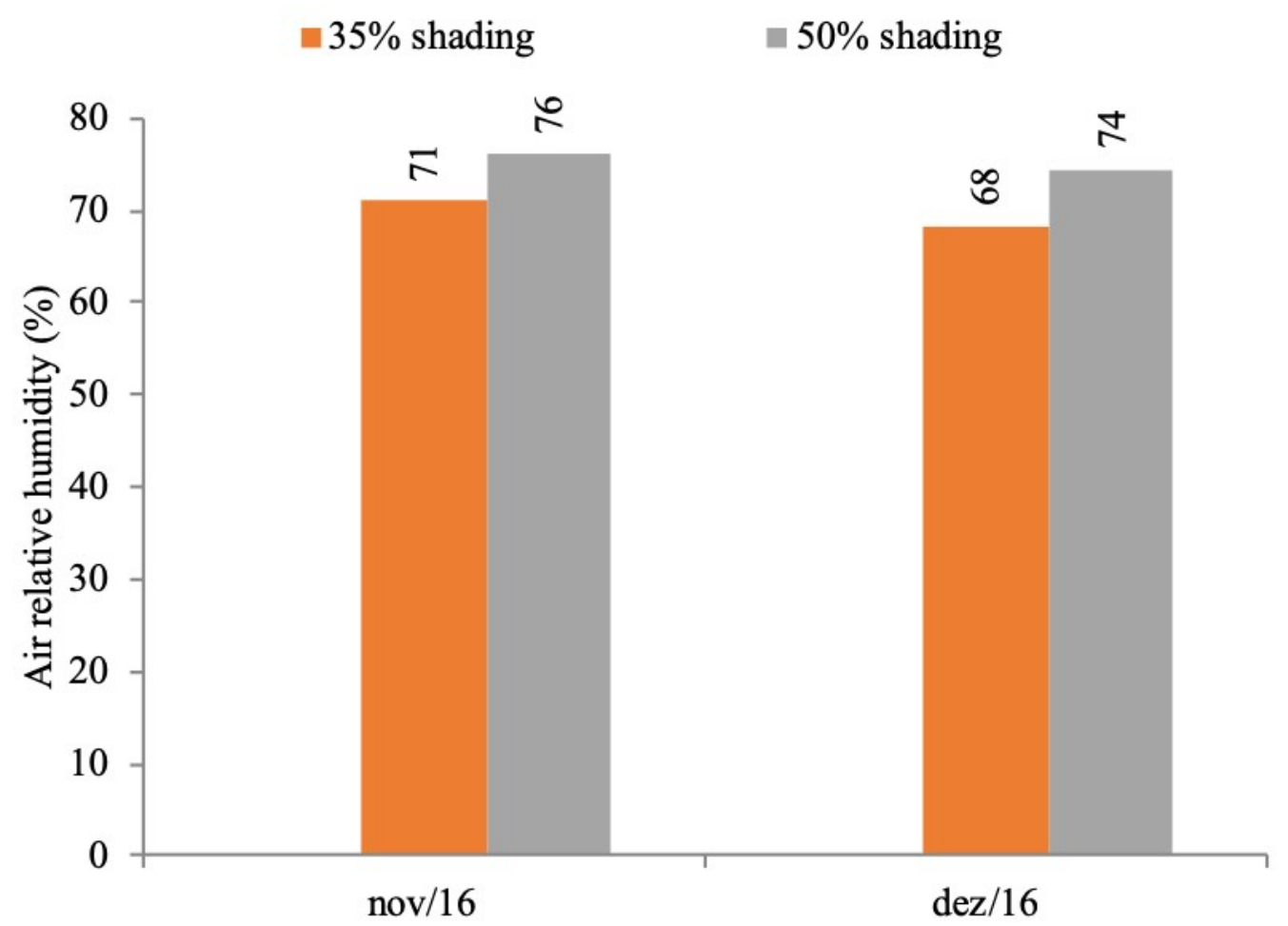

FIGURE 2. Relative humidity records in the cultivation environment. Cassilândia-MS (Brazil), 2016. 


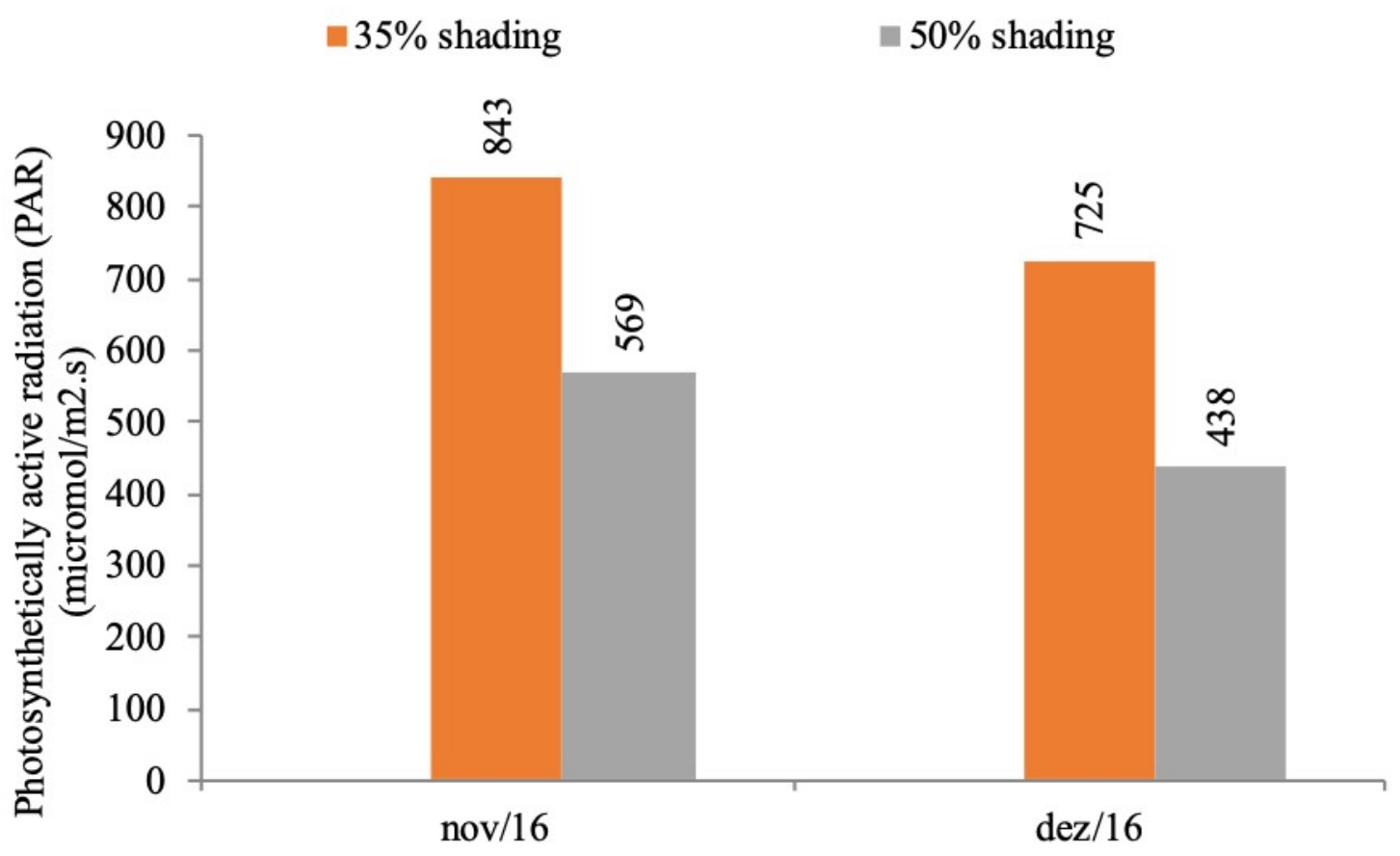

FIGURE 3. Photosynthetically active radiation (PAR) in the cultivation environment. Cassilândia-MS (Brazil), 2016.

Each cultivation environment (shading level) was considered an experiment since there were no repetitions. Each experiment was run in a completely randomized design (CRD). Treatments consisted of PBZ application methods, with 5 replications and 5 seedlings per plot. The environments were evaluated by analysis of groups of experiments.

Data were subjected to analysis of variance (F-test). Means compared by Tukey's test $(p<0.05)$ for PBZ application methods, and F-test for cultivation environments.

\section{RESULTS AND DISCUSSION}

Higher seedlings were observed in the more shaded environment $(50 \%)$, with a longer distance between stem nodes (Figure 3) due to photomorphogenesis (Table 2). As for application method, both total- and half-dose PBZ in substrate resulted in shorter seedlings since this inhibitor was active in substrate, hence constantly absorbed by the plants. It happened because PBZ partially inhibits gibberellin biosynthesis, which regulates seedling stem elongation. A similar finding was reported by Moraes et al. (2013), who evaluated jatobá seedlings (Hymenaea courbaril) and found smaller seedlings when treated with PBZ.

TABLE 2. Paricá seedling height, stem diameter, and height: diameter ratio (H/CD) as a function of growing environment and paclobutrazol (PBZ) application method. UEMS, Cassilândia-MS (Brazil), 2017.

\begin{tabular}{|c|c|c|c|}
\hline Treatment & $\begin{array}{c}\text { Seedling height } \\
---\mathrm{cm}---\end{array}$ & $\begin{array}{c}\text { Seedling diameter } \\
\text {---mm-- } \\
\end{array}$ & $\mathrm{H} / \mathrm{CD}$ \\
\hline \multicolumn{4}{|l|}{ Environment } \\
\hline $35 \%$ shading & $24.22 \mathrm{~b}$ & $4.22 \mathrm{~b}$ & $5.75 \mathrm{a}$ \\
\hline $50 \%$ shading & $26.32 \mathrm{a}$ & $4.53 \mathrm{a}$ & $5.78 \mathrm{a}$ \\
\hline \multicolumn{4}{|c|}{ PBZ application method } \\
\hline Control & $31.04 \mathrm{a}$ & $4.64 \mathrm{a}$ & $6.73 \mathrm{a}$ \\
\hline $100 \%$ seed $(\mathrm{Se})$ & $27.20 \mathrm{~b}$ & $4.64 \mathrm{a}$ & $5.89 \mathrm{~b}$ \\
\hline $100 \%$ substrate $(\mathrm{S})$ & $21.39 \mathrm{c}$ & $4.02 \mathrm{~b}$ & $5.33 \mathrm{bc}$ \\
\hline $50 \% \mathrm{Se}+50 \% \mathrm{~S}$ & $21.43 \mathrm{c}$ & $4.20 \mathrm{~b}$ & $5.10 \mathrm{c}$ \\
\hline $\mathrm{CV} \%$ & 9.27 & 8.05 & 10.23 \\
\hline
\end{tabular}

Means followed by different letters in columns, for each factor, differ significantly from each other by the F-test ( $<<0.05)$ for the growing environment and by the Tukey's test $(\mathrm{p}<0.05)$ for paclobutrazol application method.

As for height, larger collar diameters were noted in the more shaded environment (Table 2). This is because to sustain a larger plant shoot requires higher secondary growth (stem thickness). With respect to application, PBZ substrate supply provided smaller diameters, corroborating plant height data. The growing environment had no influence on $\mathrm{H} / \mathrm{CD}$ ratio. But lower ratios were obtained by applying 50\% $\mathrm{PBZ}$ in seeds and 50\% in substrate, not differing from $100 \%$ application in substrate. This shows that the effect of substrate-supplied PBZ persists longer than that of foliar application. Hence, more compact seedlings were produced, which were, on average, between $21 \%$ and $31 \%$ lower in height than those in control and in $100 \%$ seed application (Table 2). A balanced growth 
relationship between seedling height and diameter tends to promote plants with an increased percentage distribution of shoot dry phytomass, which makes seedlings more robust.

Regarding root dry biomass, PBZ application methods had an effect on the seedlings grown under $35 \%$ shading. Control treatment showed lower root biomass than those observed for 50\% PBZ via seeds and 50\% via substrate, and for $100 \%$ via substrate (Table 3). PBZ use caused changes in dry biomass distribution, increasing accumulation in roots. This is beneficial for seedlings and can further improve survivability in the field, where plants may face water stress. According to Santos \& Carlesso (1998), root-explored soil volume and root-soil contact area are essential for effective water absorption. Soil-root contact surface is maximized by emission of rootlets, which thus increases water absorption capacity of plants. Conversely, growth environment had no effect on Paricá seedlings root dry phytomass (Table 3 ).

Regarding shoot dry matter, PBZ application had an influence on seedlings under 50\% shading. Applications of PBZ 50\% via seeds and 50\% via substrate, as well as $100 \%$ via substrate, provided smaller shoot phytomass (Table 3). Therefore, this growth regulator influenced seedling shoot growth in more shaded environment. Growth environment also had effect on shoot dry weight of seedlings both for control and 100\% PBZ via seeds, wherein $50 \%$ shading provided higher values. However, the opposite was observed for $100 \%$ PBZ via substrate and $50 \%$ via substrate and $50 \%$ via seed.

TABLE 3. Variance analysis of the root, shoot, and total dry phytomass of paricá seedlings as a function of growing environment and paclobutrazol (PBZ) application methods. UEMS, Cassilândia-MS (Brazil), 2017.

\begin{tabular}{|c|c|c|}
\hline \multirow{2}{*}{ PBZ application method } & \multicolumn{2}{|c|}{ Growing environment } \\
\hline & $35 \%$ shading & $50 \%$ shading \\
\hline & \multicolumn{2}{|c|}{ Root dry phytomass $\left(\right.$ g seedling $\left.^{-1}\right)$} \\
\hline Control & $0.407 \mathrm{~A} \quad \mathrm{~b}$ & $0,520 \mathrm{~A} \mathrm{a}$ \\
\hline $100 \%$ via seeds & $0.544 \mathrm{~A} \mathrm{ab}$ & $0,586 \mathrm{~A} \mathrm{a}$ \\
\hline $100 \%$ via substrate & $0.667 \mathrm{~A} \mathrm{a}$ & $0,553 \mathrm{~A} \mathrm{a}$ \\
\hline $50 \%$ via seeds $+50 \%$ via substrate & $0.612 \mathrm{~A} \mathrm{a}$ & $0,562 \mathrm{~A} \mathrm{a}$ \\
\hline \multirow[t]{2}{*}{$\mathrm{CV} \%$} & \multicolumn{2}{|c|}{16.28} \\
\hline & \multicolumn{2}{|c|}{ Shoot dry phytomass (g seedling ${ }^{-1}$ ) } \\
\hline Control & $0.853 \mathrm{~B} \mathrm{a}$ & $1.246 \mathrm{~A} \mathrm{a}$ \\
\hline $100 \%$ via seeds & $0.706 \mathrm{~B}$ a & $1.297 \mathrm{~A} \mathrm{a}$ \\
\hline $100 \%$ via substrate & $0.607 \mathrm{~A} \mathrm{a}$ & $0.706 \mathrm{~A} \mathrm{~b}$ \\
\hline $50 \%$ via seeds $+50 \%$ via substrate & $0.581 \mathrm{~A} \mathrm{a}$ & $0.639 \mathrm{~A} \mathrm{~b}$ \\
\hline \multirow[t]{2}{*}{$\mathrm{CV} \%$} & \multicolumn{2}{|c|}{28.99} \\
\hline & \multicolumn{2}{|c|}{ Total dry phytomass $\left(\mathrm{g}\right.$ seedling ${ }^{-1}$ ) } \\
\hline Control & $1.261 \mathrm{~B} \mathrm{a}$ & $1,766 \mathrm{~A}$ a \\
\hline $100 \%$ via seeds & $1.250 \mathrm{~B} \mathrm{a}$ & $1,883 \mathrm{~A} \mathrm{a}$ \\
\hline $100 \%$ via substrate & $1.275 \mathrm{~A} \mathrm{a}$ & $1,179 \mathrm{~A} \mathrm{~b}$ \\
\hline $50 \%$ via seeds $+50 \%$ via substrate & $1.194 \mathrm{~A} \mathrm{a}$ & $1,202 \mathrm{~A} \mathrm{~b}$ \\
\hline $\mathrm{CV} \%$ & & \\
\hline
\end{tabular}

Means followed by different uppercase letters in the rows and lowercase letters in the columns differ significantly from each other by the Ftest and Tukey's test $(\mathrm{p}<0.05)$, respectively.

Under 50\% shading, PBZ 50\% via seed and 50\% via substrate, as well as $100 \%$ via substrate, provided lower total dry phytomass yield, which is due to the shoot dry phytomass mentioned above (Table 3 ). Some plants are more sensitive to photoinhibition when exposed to higher irradiance (brightness) and less able to repair photosynthetic damage, thus affecting growth and consequent accumulation of dry phytomass. This fact was verified in control and $100 \% \mathrm{PBZ}$ via seed (under $35 \%$ shading). In the latter, growth regulator effect was less persistent during plant growth. According to Sharma \& Awasthi (2005), PBZ is persistent and its concentration increases in the soil as a function of number of applications; yet in fruit, it persists less, and is not found in ripe fruits.

The highest total dry biomass (Table 3) of plants under $50 \%$ shading was influenced by shoot dry biomass
(Figures 1, 2, and 3). The most intense shading might have maintained net photosynthesis at the highest level, reflecting in plant growth. On the other side, higher light incidence leads to higher leaf warming due to infrared radiation. Moreover, relative humidity was lower in the less shaded conditions, which may have affected stomata guard cell turgidity and caused a reduction in daily opening time of stomata.

The lower PAR in the darker environment (Figure 3) did not limit photosynthesis rate, as plants in shaded environments undergo physiological changes that often improve PAR use efficiency for photosynthesis.

Applying $100 \%$ PBZ via substrate was more practical, besides producing smaller seedlings with lower $\mathrm{H} / \mathrm{CD}$ ratios than control. Under $50 \%$ shading, this application method provided seedlings with the most 
suitable phytomass distribution, $47 \%$ only in roots compared to the $29 \%$ of control. Seedlings with larger proportions of root mass have better field survivability; they also showed lower total dry weight. The higher the total dry phytomass, the higher the photoassimilate (respiration) expenditure for plant structure maintenance.

Araújo et al. (2017) and Caione et al. (2012) verified, in paricá seedlings at $52 \mathrm{DAE}$ and $90 \mathrm{DAS}$, ratios between shoot and root dry matter ranging from 2 and 6 , and from 3.2 to 3.7 , respectively. In the present study, we evidenced that $100 \% \mathrm{PBZ}$ via substrate allowed paricá seedlings a ratio of 1.3 compared to the control of 2.4 , under $50 \%$ shading. In this production system seedlings had increased dry phytomass partitioning to the roots, increasing their soil exploitation capacity when in the field. This also allows greater tolerance to water stress and improved growth in the field, as absorption of water and inorganic nutrients is increased.

\section{CONCLUSIONS}

The growing under 50\% shading improved quality of paricá seedlings since this environment enhanced growth conditions.

Application of paclobutrazol $100 \%$ via substrate provided compact seedlings with increased dry phytomass partitioning to the roots, besides being a practical method.

\section{ACKNOWLEDGMENTS}

The authors thank the Conselho Nacional de Desenvolvimento Científico e Tecnológico (CNPq) and Fundação de Apoio ao Desenvolvimento do Ensino, Ciência e Tecnologia do Estado de Mato Grosso do Sul (Fundect), for the financial support (FUNDECT/CNPq/PRONEM 15/2014; FUNDECT/UNIVERSAL-MS 11/2014 and CNPq/UEMS/ PIBIC).

\section{REFERENCES}

Araújo EF, Aguiar AS, Arauco AMS, Gonçalves EO, Almeida KNS (2017) Crescimento e qualidade de mudas de Paricá produzidas em substratos à base de resíduos orgânicos. Nativa 5(1):16-23. DOI:

https://dx.doi.org/10.5935/2318-7670.v05n01a03

Benett KS, Faria Junior MJA, Benett CGS, Seleguini A, Lemos OL (2014) Utilização de paclobutrazol na produção de mudas de tomateiro. Comunicata Scientiae 5(2):164-169.

Braga LF, Oliveira AC, Sousa MP (2013) Morfometria de sementes e desenvolvimento pós-seminal de Schizolobium amazonicum Huber (Ducke) - Fabaceae. Científica 41(1):01-10. DOI: http://dx.doi.org/10.15361/19845529.2013v41n1p01-10

Caione G, Lange A, Schoninger EL (2012) Crescimento de mudas de Schizolobium amazonicum (Huber ex Ducke) em substrato fertilizado com nitrogênio, fósforo e potássio. Scientia Forestalis 40(94): 213-221.
Carvalho PER (2007) Paricá Schizolobium amazonicum. Colombo, Embrapa Florestas, 8p. (Circular técnica 142).

Dapont EC, Silva JB, Oliveira JD, Alves CZ, Dutra AS (2014) Métodos para acelerar e uniformizar a emergência de plântulas de Schizolobium amazonicum. Revista Ciência Agronômica 45(3):598-605.

Gondin JC, Silva JB, Alves CZ, Dutra AS, Junior LE (2015) Emergência de plântulas de Schizolobium amazonicum Huber ex Ducke (CAESALPINACEAE) em diferentes substratos e sombreamentos. Revista Ciência Agronômica 46(2):329-338. DOI:

http://dx.doi.org/10.5935/1806-6690.20150012

Kluge RA, Uliana JVT, Silva PPM (2015) Aspectos Fisiológicos e Ambientais da Fotossíntese. Revista virtual de química 7(1):56-73.

Lenhard NR, Paiva Neto VB, Scalon SPQ, Alvarenga AA (2013) Crescimento de mudas de pau-ferro sob diferentes níveis de sombreamento. Pesquisa Agropecuária Tropical 43(2): 178-186. DOI: http://dx.doi.org/10.1590/S198340632013000200012

Moraes CB, Uesugi G, Ono EO, Rodrigues JD, Guerrini IA, Mori ES (2013) Influência do uso de biorreguladores no crescimento de Hymenaea courbaril. Revista Instituto Florestal 25(2):223-229.

Rosa LS, Vieira TA, Santos DS, Silva LCB (2009) Emergência, crescimento e padrão de qualidade de mudas de Schizolobium amazonicum Huber ex Ducke sob diferentes níveis de sombreamento e profundidades de semeadura. Revista de Ciências Agrárias 52(1):87-98.

Sharma D, Awasthi MD (2005) Uptake of soil applied paclobutrazol in mango (Mangifera indica L.) and its persistence in fruit and soil. Chemosphere 60(2):164-9. DOI: http://dx.doi.org/10.1016/j.chemosphere.2004.12.069

Santos RF, Carlesso R (1998) Déficit hídrico e os processos morfológicos e fisiológicos das plantas. Revista Brasileira de Engenharia Agrícola e Ambiental 2(3):287294. DOI: http://dx.doi.org/10.1590/18071929/agriambi.v2n3p287-294

Seleguini A, Faria Júnior MJA, Benett KSS, Lemos OL, Seno S (2013) Estratégias para produção de mudas de tomateiro utilizando paclobutrazol. Semina: Ciências Agrárias 34(2):539-548. DOI: http://dx.doi.org/10.5433/1679-0359.2013v34n2p539

Valadão MBX, Marimon BH, Reis SM, Oliveira B, Oliveira EM, Marimon BS (2014) Initial development and biomass partitioning of Physocalymma scaberrimum Pohl (Lythraceae) under different shading levels. Scientia Forestalis 42(101):129-139. 